\title{
PLASMAPHERESIS EDEMA. II. THE EFFECT OF REDUCTION OF SERUM PROTEIN ON THE ELECTROLYTE PATTERN AND CALCIUM CONCENTRATION
}

\author{
BY DANIIEL C. DARROW, EDWARD B. HOPPER, AND M. KATHARINE CARY
}

(From the Department of Pediatrics, Yale University School of Medicine, New Haven)

(Received for publication March 14, 1932)

In a previous paper (1) it was shown that, when the concentration of serum protein had been reduced to about three per cent by plasmapheresis, dogs became edematous. The type of edema produced in this way is probably most closely analogous to that of nutritional edema.

In connection with the work on dogs reported in that paper, certain studies of serum and ascitic electrolytes were undertaken and will be discussed in this paper. Physiological saline was injected into two additional dogs to determine the effect of this procedure on serum electrolytes under conditions similar to those of the plasmapheresis experiments.

\section{METHODS}

About eighteen hours after previous bleedings or administration of salt solution, blood was withdrawn from a femoral artery or jugular vein and was allowed to clot under oil. Serum was used for all analyses. Ascitic fluid was taken at necropsy in Experiments III and V but in the other cases by abdominal paracentesis. The following chemical methods were used: Bicarbonate, manometric' method of Van Slyke and Neill (2) using $0.2 \mathrm{ml}$; ; chloride, Van Slyke (3) using potassium permanganate, to oxidize the proteins; phosphate, Benedict and Theis (4); total base, Stadie and Ross's (5) modification of the Fiske method without removing phosphate or applying a correction for phosphate; nitrogen by gross $\mathrm{Kjeldahl}$ on $1 \mathrm{ml}$. of serum using thirty per cent hydrogen peroxide to facilitate complete oxidation; nonprotein nitrogen, Folin and Wu (6); and calcium, Clark and Collip's (7) modification of Kramer and Tisdall's method. Albumin was determined by the Howe (8) method of precipitating globulin with $\mathrm{Na}_{2} \mathrm{SO}_{4}$ in the first two experiments and in the third experiment up to the eighth day. Thereafter, Howe's method using a mixture of $\mathrm{KH}_{2} \mathrm{PO}_{4}$ and $\mathrm{K}_{2} \mathrm{HPO}_{4}(1: 2)$ to precipitate the globulin was adopted. The two methods give essentially identical results but we have found the phosphate method somewhat more consistent from day to day. Total nitrogen minus nonprotein nitrogen was multiplied by 6.25 to obtain protein. All determinations except phosphate and nonprotein nitrogen were run in duplicate.

All analyses are expressed in milli-equivalents (m.eq.) of univalent base per liter of serum. In converting protein to equivalents of base, the factors of Van Slyke, Hastings, Hiller and Sendroy (9) were used, namely, albumin per cent $\times 2.73$ and globulin per cent $\times 1.87$. Total carbon dioxide was converted to bicarbonate at $\mathrm{pH} 7.38$ by multiplying carbon dioxide volumes per 
cent by 0.423 . Dibasic and monobasic phosphate were assumed to occur in the ratio of $4: 1$.

The values for concentrations in m.eq. per liter were converted to m.eq. per kilogram of water in calculating the data represented in Chart 2. The following formula of Van Slyke, Wu and McLean (10) was used for this purpose: water $=.99-0.8 P$, in which $P$ is the protein in per cent. This formula has been tested a number of times and found to agree satisfactorily with the dried weight except in plasma having a large amount of lipoid. It should be pointed out that although dried weight is not the same as water content, the error of such an assumption is probably small.

The experiments I, II, III, IV and V consisted of bleeding once or twice a day, centrifuging the citrated blood and returning the erythrocytes suspended in 0.9 per cent solution of $\mathrm{NaCl}$ after first removing the plasma. In order to facilitate the production of a considerable amount of edema, 0.9 per cent $\mathrm{NaCl}$ solution was given by gavage when the serum proteins had reached the level at which edema might be expected. The experiments should affect the electrolyte pattern of the blood (1) by reduction of the plasma protein concentration, (2) because of the administration of considerable quantities of $\mathrm{NaCl}$, (3) through loss of blood and (4) perhaps by undefinable effects of the various experimental procedures. The hematocrit figures reported in the previous paper show that loss of erythrocytes should not effect the electrolyte pattern to any considerable extent. The reduction of hematocrit was from about thirty-five to twenty-five per cent. It was felt that the elapse of eighteen hours between the administration of salt solution and obtaining the sample of blood would allow any disturbance due to the $\mathrm{NaCl}$ solution to be adjusted so that the blood samples would represent essentially the effects of reduction of plasma protein. Nevertheless, as a control, two dogs were subjected to daily intravenous injections of 0.9 per cent $\mathrm{NaCl}$ and specimens removed in the morning. This duplicated the procedure of the previous experiments except for the plasmapheresis. The amount of saline injection in the control dogs is greater than that injected in the plasmapheresis experiments, but considerably less than the amount of saline given by gavage.

The data will be presented from three points of view: (1) the effect of change in serum protein concentration on the electrolyte pattern of the serum; (2) a comparison of the concentrations of ascitic fluid electrolytes with those of arterial and venous serum; (3) the effect of change in protein concentration on calcium concentration.

\section{The effect of change in serum protein on serum electrolytes}

Table I presents the data of the plasmapheresis experiments in detail. The following specimens are distinctly aberrant: the serum and ascitic fluids in Experiment II on the tenth day, which were taken about six hours after injection of physiological salt solution and which showed 
TABLE I

Electrolyte concentration of blood serum and ascitic fluid

\begin{tabular}{|c|c|c|c|c|c|c|c|c|c|c|c|}
\hline $\begin{array}{l}\text { Experi- } \\
\text { ment } \\
\text { num- } \\
\text { ber }\end{array}$ & Day & Sample* & Edema & $\mathrm{HCO}_{3}^{-}$ & $\mathrm{Cl}^{-}$ & $\begin{array}{l}\text { Albu- } \\
\text { min- }\end{array}$ & $\begin{array}{c}\text { Globu- } \\
\text { lin- }\end{array}$ & $\mid \begin{array}{l}\mathrm{H}_{2} \mathrm{PO}_{4}^{-} \\
\mathrm{HPO}^{-}\end{array}$ & $\begin{array}{l}\text { Total } \\
\text { base }\end{array}$ & $\begin{array}{c}\text { Serum } \\
\text { non- } \\
\text { protein } \\
\text { nitro- } \\
\text { gen }\end{array}$ & $\underset{\mathrm{Ca}}{\text { Serum }}$ \\
\hline & & & & m.eq. & m.eq. & m.eq. & m.eq. & m.eq. & m.eq. & $\underset{\substack{\text { mgm } \\
\text { per } \\
\text { ml. }}}{.00}$ & $\begin{array}{c}\text { pgm. } \\
\text { per } 100 \\
m l .0\end{array}$ \\
\hline I & -27 & VB & 0 & 20.6 & 104.4 & 10.0 & 4.6 & & 153.0 & & \\
\hline I & 4 & VB & 0 & 24.9 & 108.9 & 6.4 & 4.6 & 2.2 & 152.0 & 27 & \\
\hline I & 7 & VB & 0 & 20.6 & 111.4 & 8.2 & 3.3 & 3.2 & 155.8 & 22 & \\
\hline I & 17 & VB & ++ & 21.0 & 114.0 & 4.3 & 2.2 & 3.1 & 147.0 & 34 & \\
\hline I & 19 & $\mathrm{AB}$ & ++ & 23.0 & 112.0 & 4.7 & 2.7 & 2.5 & 159.5 & 30 & \\
\hline I & 19 & VB & ++ & 24.4 & 111.0 & 5.0 & 2.7 & 2.6 & 163.0 & 30 & 9.9 \\
\hline I & 19 & $\mathrm{AbF} 1$ & ++ & 25.2 & 119.0 & 0.0 & 0.0 & 3.0 & 158.5 & 30 & 7.5 \\
\hline I & 23 & $\mathrm{AB}$ & 0 & 20.8 & 113.2 & 8.0 & 3.0 & 4.1 & 151.4 & 39 & \\
\hline I & 23 & VB & 0 & 22.5 & 111.2 & 8.0 & 3.0 & 4.1 & 152.6 & 39 & \\
\hline II & -61 & AB & 0 & 21.8 & 111.2 & 5.9 & 8.3 & & 151.3 & 29 & \\
\hline II & -12 & VB & 0 & 22.4 & 112.6 & 8.8 & 5.8 & 3.3 & 155.8 & 44 & \\
\hline II & 10 & AB & ++ & 13.0 & 133.0 & 2.8 & 1.4 & 4.1 & 179.1 & 40 & \\
\hline II & 10 & VB & ++ & 13.8 & 133.7 & 2.9 & 1.3 & 4.1 & 179.4 & 40 & \\
\hline II & 10 & $\mathrm{AbFl}$ & ++ & 14.2 & 137.6 & 0.0 & 0.0 & 3.4 & 165.3 & 39 & \\
\hline III & 1 & VB & 0 & 22.7 & 104.2 & 11.0 & 2.5 & 3.0 & 156.4 & 23 & 12.3 \\
\hline III & 2 & VB & 0 & 25.7 & 106.6 & 12.5 & 1.6 & 2.4 & 159.4 & 2 & 12.2 \\
\hline III & 3 & VB & 0 & 23.9 & 107.8 & 9.9 & 3.0 & 2.5 & 166.6 & 22 & 11.9 \\
\hline III & 8 & VB & + & 19.6 & 118.4 & 7.5 & 0.4 & 3.0 & 165.8 & 31 & 9.2 \\
\hline III & 11 & AB & ++ & 19.6 & 114.6 & 4.5 & 2.3 & 2.8 & 145.9 & 26 & 8.7 \\
\hline III & 11 & VB & ++ & 20.6 & 112.6 & 4.5 & 2.8 & 2.8 & 151.0 & 26 & 9.7 \\
\hline III & 11 & $\mathrm{AbFl}$ & ++ & 22.8 & 121.4 & 0.3 & 0.0 & 2.2 & 153.3 & 26 & 6.8 \\
\hline IV & 1 & VB & 0 & 19.2 & 116.4 & 11.8 & 3.4 & 3.2 & 164.7 & & \\
\hline IV & 2 & VI & 0 & 6 & 108.4 & 11.4 & 1.9 & 3.2 & 153.0 & & 13.1 \\
\hline IV & 4 & VB & 0 & 23.0 & 115.4 & 10.4 & 3.5 & 2.9 & 162.0 & & 12.1 \\
\hline IV & 5 & VB & +- & 26.8 & 110.6 & (11.0) & & 2.7 & 159.8 & 39 & 12.1 \\
\hline IV & 6 & VB & +- & 25.7 & 113.6 & 9.2 & 0.9 & 2.6 & 161.6 & & \\
\hline IV & 7 & VB & - & 24.9 & 112.2 & 7.6 & 1.0 & 2.6 & 162.8 & & 12.0 \\
\hline IV & 8 & VB & +- & 23.8 & 114.8 & 8.7 & 0.9 & 2.5 & 157.6 & 32 & 12.1 \\
\hline IV & & VB & +- & 25.1 & 113.8 & 7.3 & 0.8 & 2.5 & 157.0 & 23 & \\
\hline IV & 10 & V & +- & 2 & & 5. & 0.8 & 2.7 & 160.4 & & \\
\hline IV & 11 & VB & + & 23.0 & 115.6 & 5.1 & 1.1 & 2.4 & 168.2 & 23 & \\
\hline IV & 12 & AB & ++ & 20.3 & 119.2 & 5.0 & $(1.5)$ & 3.5 & 159.0 & 22 & 10.4 \\
\hline IV & 12 & VB & ++ & 22.6 & 112.2 & 5.4 & 1.6 & & 160.8 & 22 & \\
\hline IV & 12 & $\mathrm{AbFl}$ & ++ & 22.8 & 126.8 & 0.0 & 0.0 & 2.7 & 157.4 & 20 & 8.4 \\
\hline IV & 13 & VB & + & 24.5 & 115.2 & & & 2.6 & & 31 & \\
\hline IV & 14 & VB & +- & 25.3 & 111.2 & 5.7 & 2.8 & & 160.2 & & \\
\hline IV & 15 & VB & 0 & 28.7 & 107.4 & 7.1 & 3.2 & 2.2 & 157.5 & 26 & \\
\hline IV & 18 & VB & 0 & 25.9 & 110.4 & 6.8 & 4.0 & 2.6 & 157.3 & 31 & 12.3 \\
\hline IV & 23 & VB & 0 & 23.4 & 109.4 & 9.3 & 3.3 & 1.7 & 152.4 & & 12.9 \\
\hline IV & 32 & VB & 0 & 22.9 & 112.0 & 10.7 & 1.8 & 3.0 & & & 11.8 \\
\hline
\end{tabular}

Same dog 11 months later

\begin{tabular}{l|r|l|l|l|l|l|l|l|l|l|l}
\hline $\mathrm{V}$ & 1 & $\mathrm{VB}$ & 0 & 22.8 & 105.8 & 8.8 & 5.3 & & 151.2 & 25 & \\
$\mathrm{~V}$ & 7 & $\mathrm{VB}$ & 0 & 22.9 & 117.0 & 6.4 & 3.6 & 1.8 & 162.8 & & \\
$\mathrm{~V}$ & 11 & $\mathrm{VB}$ & + & 20.5 & 118.2 & 4.3 & 2.5 & & 159.2 & & \\
$\mathrm{~V}$ & 13 & $\mathrm{AB}$ & + & 18.7 & 121.4 & 3.5 & 2.7 & 2.2 & 162.8 & & \\
$\mathrm{~V}$ & 13 & $\mathrm{VB}$ & + & 19.6 & 119.6 & 3.3 & 2.9 & 2.2 & 151.2 & 22 & \\
$\mathrm{~V}$ & 13 & $\mathrm{AbFl}$ & + & 17.2 & 125.6 & 1.9 & & & 163.2 & 26 & \\
\hline
\end{tabular}

* $\mathrm{AB}=$ Arterial blood.

$\mathrm{VB}=$ Venous blood.

$\mathrm{AbFl}=$ Abdominal fluid. 
high chloride and total base, and low bicarbonate; the serum in Experiment IV on the second day when the bicarbonate was unexplainably low; and the ascitic fluid in Experiment $\mathrm{V}$ which was contaminated with blood and suffered a good deal of exposure before analysis. The results on these samples were not used in the analysis of the data.

The data give one an opportunity to observe the effect of a change in protein concentration on the concentration of bicarbonate, chloride and total base. The general trend of the results can be appreciated best by examining Charts 1 and 2 . In Chart 1 the concentrations of bicarbon-

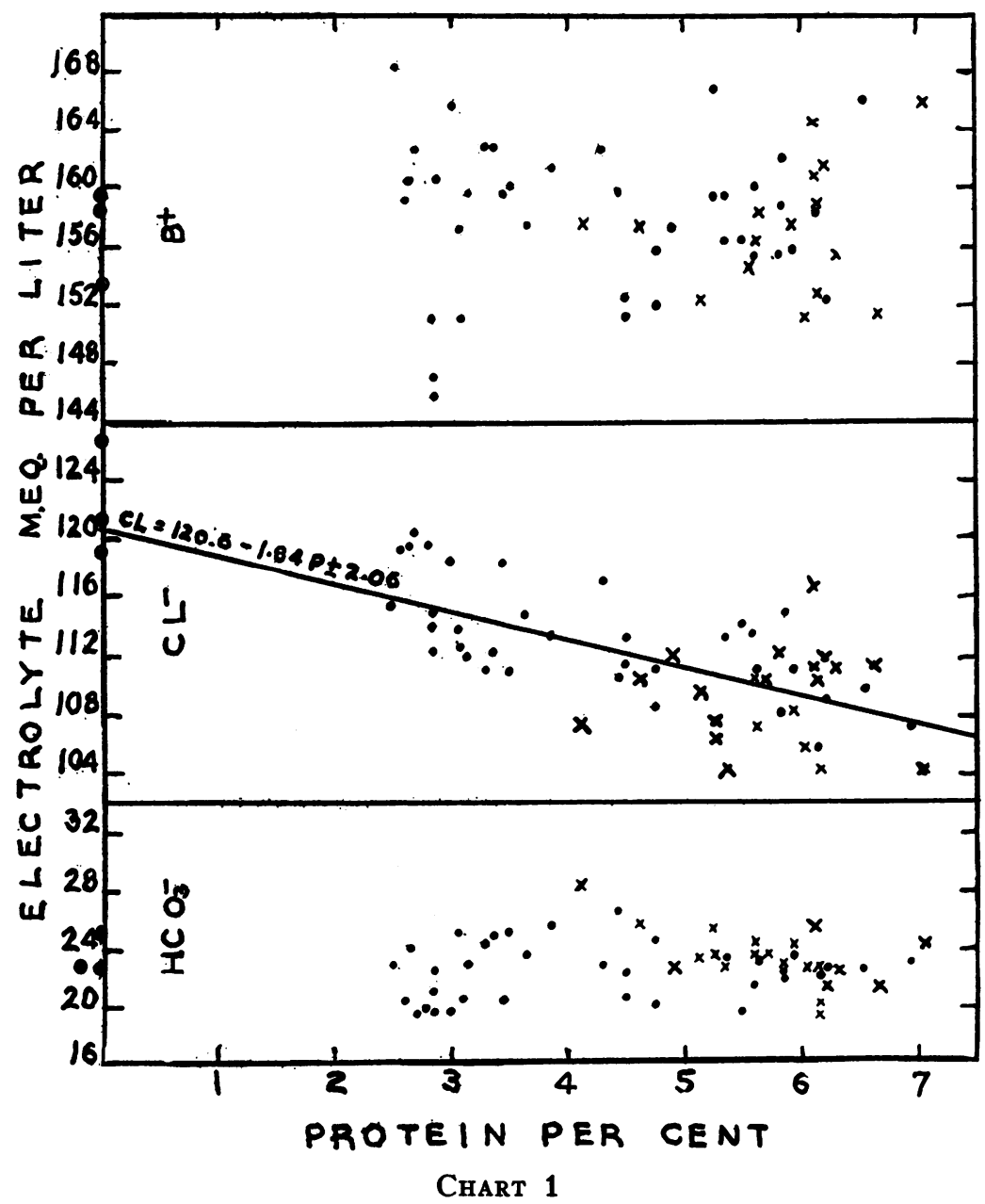

ate, chloride and total base per liter of serum are represented as related to protein per cent. Chart 2 shows the same relationship when all concentrations are expressed per kilogram of serum water. The original values 
were converted to concentrations per kilogram of serum water by the formula previously mentioned. The purpose of Chart 2 is to eliminate the effects that are brought about by the varying content of serum water which accompanies the large changes in serum protein concentration. Although the formula for estimating water content from protein per cent expresses dried weight rather than water content, it is probably

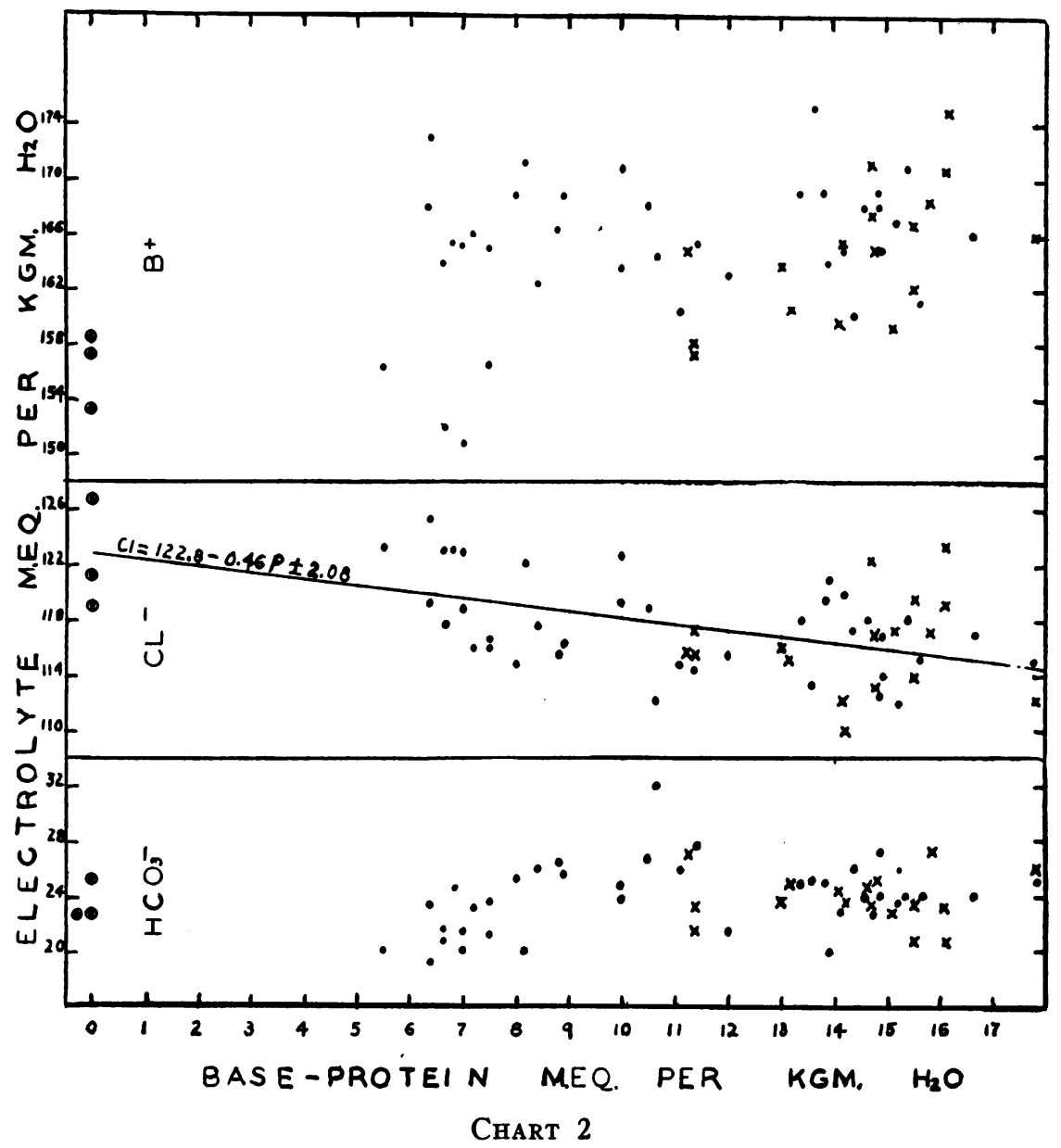

sufficiently accurate for our purpose. In Chart 2, the protein per cent is converted to base combining power, since the base combining power of the proteins is the factor most likely to affect electrolyte concentration if the effect of protein on water content is eliminated. In both charts the data of serums taken over forty hours after any previous administration of salt solution are represented by $x$ 's, those of serums taken about eighteen hours after administration of salt solution by dots and those of the 
ascitic fluids by dots surrounded by circles. The figures obtained in both the control (see Table II) and the plasmapheresis experiments are represented on the charts. The introduction of the data of the control animals does not significantly alter the interpretation of the results which would be obtained if only the data of the plasmapheresis animals had been used.

Inspection of the charts reveals that the distribution of bicarbonate and total base is not significantly affected by the change in protein concentration. Both bicarbonate and base are somewhat more widely scattered than normal but this dispersion does not seem to be brought about by the injection of salt solution since the $x$ 's and dots have about the same distribution.

Chart 1 shows that the chloride varies inversely with the protein. The line of regression ${ }^{1}$ is represented on the chart and the equation of this is: $(\mathrm{Cl})_{s}=120.64-1.87 P \pm 2.06$ where $(\mathrm{Cl})$, is chloride in m.eq. per liter, $P$ is protein per cent, and \pm 2.06 is the probable error. The probable error of the slope (or regression coefficient) is \pm 0.21 . The equation was derived without using the data of the ascitic fluids, but it should be noted that the latter are in fairly good agreement with the value predicted by the regression equation for serum with no protein.

Chart 2 shows a similar inverse relationship between chloride and base-protein when the concentrations are expressed per kilogram of serum water. The line of regression is: $(\mathrm{Cl})_{\odot}=122.8-0.46(\mathrm{BP}) \pm 2.08$ where $(\mathrm{Cl})_{s}$ is chloride in m.eq. per kilogram of serum water, $(\mathrm{BP})$ is the base combining power of the serum proteins in m.eq. per kilogram of serum water and \pm 2.08 is the probable error. The probable error of the slope (or regression coefficient) is \pm 0.08 . The equation predicts a concentration of chloride for a serum with no protein that agrees somewhat better with those of the ascitic fluids than the previous equation.

It will be noticed that the high chloride values occur chiefly in the serums which may be affected by the administration of salt solution. In the plasmapheresis experiments, this necessarily occurred, since it is difficult to maintain a low level of serum protein without continuous bleeding and the accompanying injection of physiological salt solution. However, the chlorides of the serum taken about eighteen hours after the

${ }^{1}$ For the statistical formulas used in the paper, the reader is referred to Dunn (Physiol. Rev., 1929, ix, 336). The regression equation is:

$$
Y-\bar{Y}=r_{x y} \frac{\sigma_{y}}{\sigma_{x}}(X-\bar{X}) .
$$

The probable error of the regression coefficient is $\pm 0.6745 \sqrt{\frac{1-r_{x y}^{2}}{n-2}}\left[\frac{\sigma_{y}}{\sigma_{x}}\right]$. This gives the variations in the slope of the line that may be due to sampling. The probable error of the $Y$ calculated from $X$ is $\pm 0.6745 \sigma_{y} \sqrt{1-r_{x y}{ }^{2}}$. This gives the variations in the predicted values that may be due to sampling. The probable error of the difference is $\sqrt{(\text { P.E. })_{1}{ }^{2}+(\text { P.E. })_{2}}$. 
administration of salt solution vary inversely with the proteins. The slope of the line representing this relationship would be somewhat less than the one drawn on the chart. It should be pointed out that if there is increase in chloride brought about only by the effect of the injection of salt solution, there is no evidence of a similar retention of sodium reflected in the values of the total base. Furthermore it can be demonstrated that the increase in chloride is not accompanied by a compensating decrease in bicarbonate although there is evidence of the well recognized inverse relationship between chloride and bicarbonate.

Collateral evidence that there is an indirect relationship between chloride and protein is furnished by the control experiments presented in Table II. These experiments were designed to obtain blood from dogs

TABLE II

Electrolyte concentration of serum of control dogs

\begin{tabular}{|c|c|c|c|c|c|c|c|c|c|c|c|c|}
\hline \multirow{2}{*}{$\begin{array}{c}\text { Dog } \\
\text { num- } \\
\text { ber }\end{array}$} & \multirow[t]{2}{*}{ Day } & \multirow[t]{2}{*}{ Weight } & \multirow[t]{2}{*}{$\mathrm{HCO}_{3}^{-}$} & \multirow[t]{2}{*}{$\mathrm{Cl}^{-}$} & \multirow[t]{2}{*}{$\begin{array}{c}\text { Albu- } \\
\min ^{-}\end{array}$} & \multirow[t]{2}{*}{$\begin{array}{c}\text { Globu- } \\
\text { lin }\end{array}$} & \multirow[t]{2}{*}{$\begin{array}{l}\mathrm{H}_{2} \mathrm{PO}_{4}^{-}- \\
\mathrm{HPO}\end{array}$} & \multirow[t]{2}{*}{$\mathrm{Ca}^{++}$} & \multirow{2}{*}{$\begin{array}{l}\text { Total } \\
\text { base }\end{array}$} & \multirow{2}{*}{$\begin{array}{l}\text { Serum } \\
\text { pro- } \\
\text { tein }\end{array}$} & \multicolumn{2}{|c|}{$\begin{array}{l}\text { Intravenous } \\
0.9 \text { per cent } \\
\mathrm{NaCl}\end{array}$} \\
\hline & & & & & & & & & & & A.M. & P.M. \\
\hline \multirow{10}{*}{6} & & kgm. & m.eq. & m.eq. & m.eq. & m.eq. & m.eq. & m.eq. & m. eq. & $\begin{array}{c}\text { grams } \\
\text { per } 100 \\
\text { ml. }\end{array}$ & $c c$. & $c c$. \\
\hline & 1 & 8.8 & 24.3 & 104.4 & 12.1 & 4.9 & & 5.9 & 155.2 & 7.04 & 450 & \\
\hline & 2 & 8.8 & 23.3 & 107.4 & 12.2 & 4.6 & 4.1 & 6.2 & & 6.94 & 350 & \\
\hline & 3 & 8.7 & 22.5 & 109.8 & 10.6 & 4.9 & & 6.6 & 156.1 & 6.55 & 350 & \\
\hline & 4 & 8.9 & 22.8 & 109.0 & 10.3 & 4.6 & & 5.8 & 152.1 & 6.19 & 450 & \\
\hline & 5 & 8.6 & 22.7 & 108.0 & 9.9 & 4.1 & & 5.9 & 155.8 & 5.83 & 475 & \\
\hline & 8 & 8.3 & 24.3 & 108.2 & 8.9 & 5.0 & 2.8 & 5.7 & 158.0 & 5.94 & 475 & 450 \\
\hline & 9 & 8.3 & 22.2 & 105.8 & & & 3.0 & 5.6 & 158.5 & 6.12 & 475 & 450 \\
\hline & 10 & 8.7 & 23.5 & 111.2 & 8.5 & 5.3 & 3.5 & & 155.8 & 5.92 & & \\
\hline & 13 & 8.6 & 23.8 & 107.0 & 8.4 & 4.7 & 2.9 & 5.9 & 156.5 & 5.61 & & \\
\hline \multirow[t]{10}{*}{7} & 1 & 9.3 & 22.5 & 110.4 & & & 2.0 & 5.9 & 158.3 & 5.69 & & \\
\hline & 8 & 9.4 & 25.7 & 110.4 & & & 3.0 & 6.1 & 158.8 & 6.11 & & \\
\hline & 20 & 9.4 & 21.9 & 112.0 & & & 2.2 & 6.1 & 161.6 & 6.21 & & \\
\hline & 31 & 9.4 & 22.5 & 111.6 & 10.7 & 3.8 & 2.6 & 6.2 & 161.0 & 6.10 & 450 & 350 \\
\hline & 32 & 9.6 & 23.8 & 111.2 & 9.4 & 3.3 & 2.1 & 5.6 & 160.7 & 5.16 & 400 & 400 \\
\hline & 33 & 9.0 & 22.0 & 112.2 & 9.4 & 4.5 & 2.7 & 5.6 & 159.0 & 5.84 & 400 & 400 \\
\hline & 34 & 9.4 & 21.7 & 113.4 & 9.2 & 4.1 & 1.8 & 5.3 & $\mathbf{1 5 5 . 5}$ & 5.56 & 450 & 450 \\
\hline & 35 & 9.4 & 19.4 & 114.4 & 9.5 & 3.8 & 2.2 & 5.3 & 156.5 & 5.48 & 450 & 450 \\
\hline & 36 & 9.6 & 23.4 & 113.2 & 9.7 & 3.4 & 1.6 & 5.3 & 159.5 & 5.36 & & \\
\hline & 41 & 9.7 & 24.4 & 111.0 & 9.8 & 3.7 & 4.0 & 5.7 & 154.7 & 5.60 & & \\
\hline
\end{tabular}

subjected to substantially the same procedures as the other animals, excepting plasmapheresis. Dividing the serums from these dogs into one group taken over forty hours after administration of salt solution and another group taken about eighteen hours after administration of salt solution, one may obtain an idea of the magnitude of the error introduced in the plasmapheresis experiments by the injection of sodium chloride. 
The average values of the two groups indicate that injection of physiological saline was accompanied by a decrease of protein of $0.13 \pm .14$ per cent, a decrease of bicarbonate of $1.18 \pm .38$ m.eq. per liter and a decrease of total base of $1.16 \pm .74 \mathrm{~m}$.eq. per liter, while there was an increase of chloride of $1.13 \pm .81 \mathrm{~m} . e q$. per liter. The changes are represented together with the probable errors of the differences. The decrease in bicarbonate is over three times the probable error, but changes in chloride, protein and total base are of about the same magnitude as the probable errors. While the number of determinations is small, the results indicate that it is not likely that a larger number of determinations would show an increase in chloride greater than 2.5 m.eq. per liter. Since the protein contents of the two groups are so nearly identical, converting the concentrations per liter to concentrations per kilogram of serum water does not significantly alter the results. The equation for chloride per liter indicates that a serum with three per cent protein has 5.6 m.eq. more chloride than a serum with six per cent protein. Hence although the slope of the line in Chart 1 might be less if some of the values were not affected by injection of salt solution, it is extremely probable that the line represents chiefly the relationship of the chloride to the protein. The equation for the chloride per kilogram of serum water indicates that the chloride of a serum with 7 m.eq. of base-protein is 3.7 m.eq. higher than that of one with 15 m.eq. base-protein. This is a little more than three times the probable difference which the control experiments indicate might be produced by the injections of salt solution. It indicates that further experiments would probably substantiate an inverse relationship between chloride and base-protein per kilogram of serum water. However, the authors prefer to regard this result as only suggestive.

The theoretical significance of the results is not clear. Presumably the chloride increases in serum with low protein in such a manner as to keep the total anion concentration constant. The increase in chloride with decrease in protein can be largely accounted for by the increase of serum water accompanying a decrease in protein. The results suggest that there is a small increase in chloride to compensate for the decrease in the base bound to protein.

It is well recognized that, in subjects with edema accompanied by low serum protein concentration, the serum chloride concentration is usually normal or high. This has been emphasized lately by Peters, Wakeman, Eisenman and Lee (11), Peters, Wakeman and Eisenman (12), Blackfan and Hamilton (13) and others. However, their data show quite irregular variations at any given protein concentration and do not permit one to express the concentration of chloride in terms of concentration of protein. Such a relationship presumably exists in man, but other factors affect the chloride in cases of nephritis and nephrosis so that the relationship is not clear cut in data from such patients. In cases of nephrosis and 
hydropigenous nephritis, the concentration of total base and, to a lesser degree, that of the bicarbonate are low. Such a change was not demonstrated in the plasmapheresis experiments.

\section{A comparison of the concentrations of electrolytes of ascitic fluid with those of arterial and venous serum}

There is little ground for assuming that a particular sample of blood is in equilibrium with ascitic fluid. To assume such an equilibrium, even approximately, the blood sample should represent the blood in the capillaries supplying the peritoneum. However, if peritoneal fluid is present in large quantities, its composition must represent an equilibrium with the average venous plasma returning from this area during the preceding few hours. An average arterial sample of plasma probably represents quite accurately the plasma supplying the peritoneum, but the venous samples that can be obtained differ from the venous plasma which is theoretically required by an amount which cannot be determined. Nevertheless, since it is desirable to know how truly plasma represents the immediate environment of cells, it is interesting to see what relationship holds between ascitic fluid and arterial and venous plasma.

The data on the ascitic fluids and arterial and venous plasma in the first four experiments are fairly suitable for this purpose. In Experiment II, the failure to get blood into the vein after withdrawal of a rather large quantity of blood was followed by symptoms of shock and acidosis. The samples were obtained only six hours after the administration of salt solution which accompanied the transfusion of cells and probably the ascitic fluid had not had time enough to come into complete equilibrium. Furthermore, the high concentration of chloride indicates that the dog had not been able to bring the composition of his blood back to normal. Though the dog appeared to be recovering, he was killed because he seemed so uncomfortable. The data of this experiment are included because they are similar to the rest in most respects. Contamination with blood and exposure to air rendered the ascitic fluid in Experiment $\mathrm{V}$ unsuitable.

Table III gives the distribution ratios for total base, bicarbonate, chloride, and bicarbonate plus chloride. All concentrations were expressed in m.eq. per kilogram of water in calculating the ratios. Since protein is largely indiffusible through capillary membranes, the concentration of protein in the ascitic fluid and blood plasma is the chief factor which should alter the distribution ratios of the freely diffusible ions. However, it is known that the distribution of calcium is altered by the fact that calcium appears to be bound to protein in an undissociated compound. Moreover, Loeb, Atchley and Palmer (14), Hastings et al. (15) and Greene et al. (16) found that the concentration of serum potassium is considerably higher than that of ascitic fluid. One does not know 
the effect of protein on the activity of the various ions, though Greene et al. have calculated the ionized base by assuming that the chloride ratios are true Donnan ratios. Until these factors are known, a theoretical ratio based on the concentration of protein and the assumption that the

TABLE III

Distribution ratios of serum and ascitic fluid (m.eq. per kilo $\mathrm{H}_{2} \mathrm{O}$ )

\begin{tabular}{c|c|c|c|c|c|c}
\hline $\begin{array}{c}\text { Experi- } \\
\text { ment } \\
\text { number }\end{array}$ & Sample & $r^{*}$ & $\frac{\left(\mathrm{B}^{+}\right)_{f}-2\left(\mathrm{Ca}^{++}\right)_{f}}{\left(\mathrm{~B}^{+}\right)_{s}-2\left(\mathrm{Ca}^{++}\right)_{s}}$ & $\frac{\left(\mathrm{HCO}_{3}^{-}\right)_{s}}{\left(\mathrm{HCO}^{-}\right)_{f}}$ & $\frac{\left(\mathrm{Cl}^{-}\right)_{s}}{\left(\mathrm{Cl}^{-}\right)_{f}}$ & $\frac{\left(\mathrm{HCO}_{3}^{-}\right)_{s}+\left(\mathrm{Cl}^{-}\right)_{s}}{\left(\mathrm{HCO}_{3}^{-}\right)_{f}+\left(\mathrm{Cl}^{-}\right)_{f}}$ \\
\hline I & AB & 0.979 & 0.97 & 0.94 & 0.98 & 0.97 \\
I & VB & 0.975 & 0.94 & 1.00 & 0.97 & 0.97 \\
II & AB & 0.988 & 0.91 & 0.94 & 0.99 & 0.98 \\
II & VB & 0.988 & 0.91 & 0.99 & 0.99 & 0.99 \\
III & AB & 0.978 & 1.02 & 0.89 & 0.98 & 0.96 \\
III & VB & 0.976 & 0.99 & 0.93 & 0.96 & 0.96 \\
IV & AB & 0.979 & 0.97 & 0.92 & 0.97 & 0.95 \\
IV & VB & 0.977 & 0.95 & 1.02 & 0.92 & 0.93 \\
\hline
\end{tabular}

* AB = Arterial blood.

$\mathrm{VB}=$ Venous blood.

$$
r=\frac{\left(\mathrm{B}^{+}\right)_{\jmath}-2\left(\mathrm{Ca}^{++}\right)_{\ell}}{\left(\mathrm{B}^{+}\right)_{\jmath}-2\left(\mathrm{Ca}^{++}\right)_{\jmath}+1 / 2(\mathrm{BP})_{d}} .
$$

$(B P)_{a}=$ Base combining equivalent of serum protein.

conditions for a true Donnan equilibrium exist can have only an empirical value. However, the desirability of expressing the relationship existing between plasma and interstitial fluid in terms of serum protein and total base justifies the use of such an empirical ratio until a better expression for this relationship is found.

In the tables, the ratio, $r$, was calculated for comparison with the ratios found. It is based on the assumptions made by Van Slyke (17) in calculating similar ratios and the formula used is as follows:

$$
r=\frac{(\mathrm{B})_{f}-(\mathrm{Ca})_{f}}{(\mathrm{~B})_{f}-(\mathrm{Ca})_{f}+0.5(\mathrm{BP})_{s}},
$$

in which $(\mathrm{B})_{f}$ is the total base of ascitic fluid; $(\mathrm{Ca})_{f}$ is calcium of ascitic fluid and $(\mathrm{BP})$, the base combining power of the serum proteins, all concentrations being expressed in m.eq. per kilogram of water. The calcium is subtracted to reduce the base to univalent terms. Ascitic base was thought to represent average conditions better than venous serum base, since a large amount of ascitic fluid is probably less subject to sudden temporary deviations from average conditions. However, as pointed out previously, the ratio, $r$, does not take into account the peculiar distribution of calcium and potassium, the presence of a probably insignificant amount of magnesium and probably other factors. 
The actual ratios agree approximately with each other and with the ratio, $r$. The agreement is best with respect to chloride and chloride plus bicarbonate, but is only fair with respect to bicarbonate and base. It is of interest that, in Experiment II, where the blood was taken 6 hours after injection of salt solution and apparently before the blood plasma had had time to come into equilibrium with the ascitic fluid, the chloride and bicarbonate ratios show about the same relation to $r$ as in the other experiments, while the base is still apparently too high in the plasma. This would indicate that the concentrations of bicarbonate and chloride can be adjusted more rapidly than base.

The experiments give about as good agreement in the ratios as those in the literature $(14,15,16,18,19)$. However, the ratios can not be used to predict the composition of ascitic, and presumably interstitial fluid in general, except as a first approximation. The wide deviation of the venous base ratio in Experiment I, of the arterial and venous bicarbonate ratios in Experiment III, and of the venous chloride ratios in Experiment IV indicate that difficulty in obtaining average blood samples is one of the sources of error. It should also be pointed out that all the ratios are quite near unity and, therefore, have considerably less value than they would have if lower. However, means have not been found to obtain interstitial fluid differing greatly in protein concentration from plasma.

\section{The effect of serum protein concentration on serum calcium concentration}

Chart 3 shows the relationship between serum protein and serum calcium. Assuming that ascitic fluid has the composition that plasma would have if free of protein, the determinations on ascitic fluid are included with those on serum. Chart 3 shows that calcium varies directly with the protein. The correlation coefficient of the calcium and protein is 0.93 \pm 0.03 . The regression equation is as follows: $(\mathrm{Ca})=0.94 P+7.45 \pm$ 0.44 , in which $(\mathrm{Ca})$ is the calcium concentration in mgm. per $100 \mathrm{ml} ., P$ is the protein per cent and \pm 0.44 is the probable error. The probable error of the regression coefficient is \pm 0.06 . When the protein concentration is zero, this would indicate a calcium concentration of $7.45 \mathrm{mgm}$. per $100 \mathrm{ml}$. which agrees well with the average value (7.5) of the ascitic fluids.

The direct relationship of calcium and protein concentration has been pointed out by Salvesen and Linder (20), Marrack and Thacker (21) and Peters and Eiserson (22). It is realized that calcium concentration is affected by the concentration of phosphate, the activity of the parathyroid glands, the amount of activated ergosterol in the body and probably other factors. The variations in phosphate in our experiments are too small to account for the differences in calcium. The data are so clear cut that they leave little doubt as to the direct relationship between calcium and protein concentration. 
Recently Stearns and Knowlton (23) analyzed the relationship between serum protein, calcium and phosphate in 76 infants and children. They concluded that there was no relationship between serum protein and calcium in non-nephritic cases. However, their data are made up of (1) a group of cord bloods, (2) a group of bloods from infants fed cod liver oil and who were under a year old, and (3) a group of children over a year old. For analysis these groups are of different value. The data show no significant correlation between the calcium and protein in the newborn cord blood or that from the children over one year old. Cord blood is not altogether satisfactory for chemical studies and probably

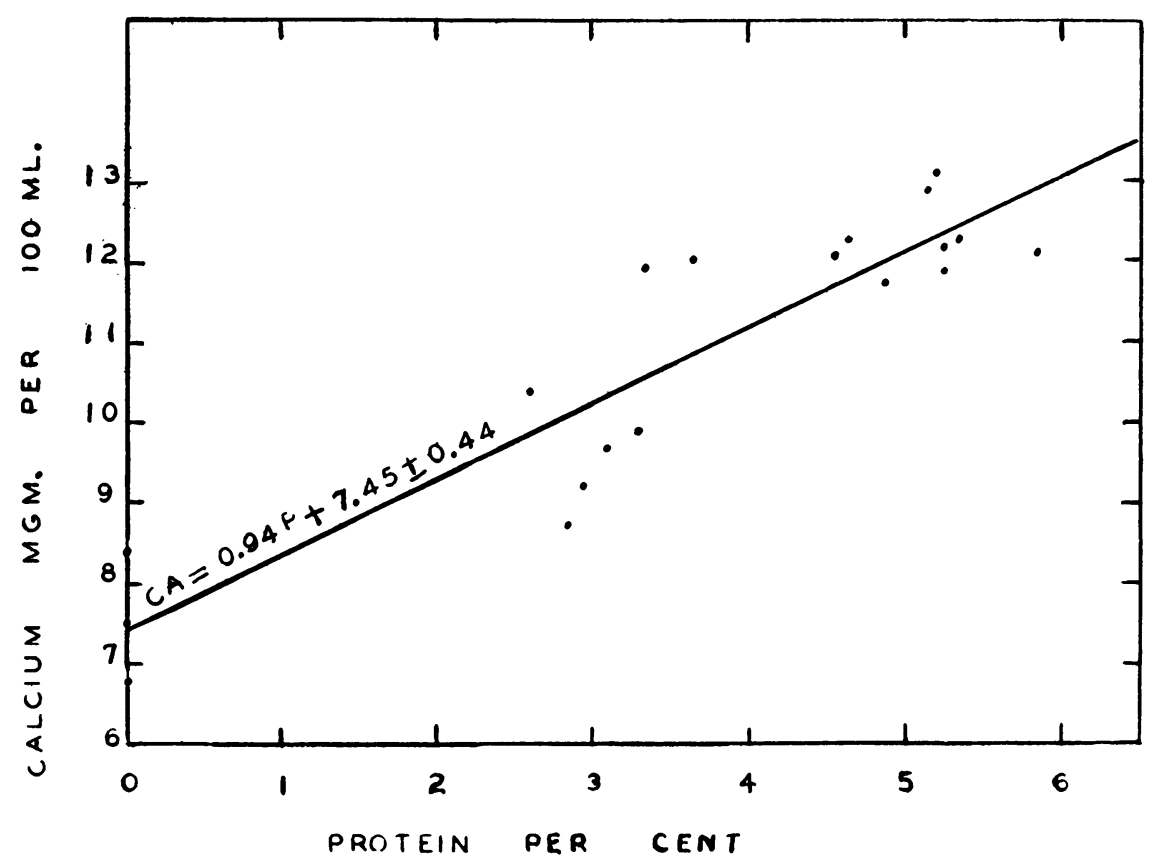

Chart 3

should be used with caution. In the group of forty-five children's serums, only one showed a very low protein concentration and this one had a normal calcium concentration. All that can be concluded from this group of cases is that variations in the calcium do not correlate with variations in the protein when there is only a small change in the protein concentration. However, the serums of the babies are quite satisfactory since they represent a uniform group from sixteen patients who had received cod liver oil and manifested a fairly wide distribution of protein. The correlation coefficient of the serum calcium and protein is $0.64 \pm .11$. The regression equation for this group is: $\mathrm{Ca}=0.41 P+8.87 \pm 0.25$. The probable error of the slope (or regression coefficient) is \pm 0.22 . The 
equation of Peters and Eiserson (22) obtained from a mixed group with many cases of nephritis is $\mathrm{Ca}=0.556 P+6$. Since the regression coefficient of the equation for the babies is $0.41 \pm 0.22$, the slope of this line cannot be considered to differ significantly from that of the line found by Peters and Eiserson. However, the constant in the latter equation differs significantly from that for the babies. The higher value for the constant in the infants presumably represents chiefly the effect of activated ergosterol in growing infants. Further data will probably show that the equation of Peters and Eiserson can be used to measure the effect of factors other than protein which modify the calcium concentration. Peters and Eiserson's equation for phosphate probably does not apply to patients fed large amounts of activated ergosterol. The general form of the equation would be $\mathrm{Ca}=0.556 P+K$. It will probably be helpful to see how far the $K$ necessary to fit any given data can be used as a measure of the effect of the factors besides protein concentration which affect the level of serum calcium.

\section{SUMMARY}

1. Electrolyte studies are reported on the serum and ascitic fluids of dogs rendered edematous by lowering the plasma protein concentration by plasmapheresis.

2. The concentrations of total base and bicarbonate show no relation to protein concentrations under the conditions of the experiments. The total base values are quite widely scattered (145 to 168 m.eq. per liter or 150 to 175 m.eq. per kilogram of serum water). The bicarbonate concentrations are also quite variable (19 to 28 m.eq. per liter or 20 to 29 m.eq. per kilogram of serum water). The control experiments demonstrated that the injection of salt solution reduced the bicarbonate and rendered these values in the plasmapheresis experiments unreliable as a reflection of change in protein concentration. While it was not demonstrated that the injection of salt solution was likely to alter the base concentration, the wide scattering of the base concentrations was probably brought about by a combination of factors inherent in the plasmapheresis experiments.

3. The concentration of chloride per liter varies inversely with that of protein according to the following regression equation: $(\mathrm{Cl})_{s}=120.64$ $-1.87 P \pm 2.06$ in which $(\mathrm{Cl})$ s is the chloride in $\mathrm{m}$. eq. per liter, $P$ the protein per cent and \pm 2.08 , the probable error.

4. The data show that chloride m.eq. per kilogram of serum water varies inversely with that of base-protein according to the following regression equation: $(\mathrm{Cl})_{s}=122.8-0.46(\mathrm{BP})_{\mathrm{s}} \pm 2.08$ in which $(\mathrm{Cl})_{\mathrm{s}}$ is chloride m.eq. per kilogram of serum water, $(\mathrm{BP})$, is the base combining power of serum protein in $\mathrm{m}$. eq. per kilogram of serum water and \pm 2.08 the probable error. 
5. The control experiments indicate that the experimental procedures were not the chief cause of the appearance of the relation expressed in the chloride equation which gives concentrations per liter of serum except inasmuch as they varied the protein concentration. However, the change in chloride per kilogram of serum water lies within the increase in chloride which might be produced by injectiong salt solution. The latter equation, though likely to be substantiated, cannot be accepted as expressing a relationship between chloride and protein at present. The slope of the line in the first equation would probably be a little less if derived from experiments not affected by the injection of salt solution but the change is not likely to alter the equation greatly.

6. The ratios

$$
\frac{\left(\mathrm{Cl}^{-}\right)_{s}}{\left(\mathrm{Cl}^{-}\right)_{f}}, \frac{\left(\mathrm{HCO}_{3}^{-}\right)_{s}}{\left(\mathrm{HCO}_{3}^{-}\right)_{f}}, \frac{\left(\mathrm{B}^{+}\right)_{f}-(\mathrm{Ca})_{f}}{\left(\mathrm{~B}^{+}\right)_{s}-(\mathrm{Ca})_{s}}
$$

agree approximately with each other. However, there is sufficient diversity in the ratios to demonstrate that a given specimen of serum is not likely to predict the composition of ascitic fluid very accurately.

7. The calcium and protein concentrations vary directly with each other according to the following regression equation: $(\mathrm{Ca})=0.94 P$ $+7.45 \pm 0.44$ in which $(\mathrm{Ca})$ is serum calcium in mgm. per $100 \mathrm{ml}$; $P$ the protein per cent and \pm 0.44 the probable error.

\section{BIBLIOGRAPHY}

1. Darrow, D. C., Hopper, E. B., and Cary, M. K., J. Clin. Invest., 1932, xi, 683. Plasmapheresis Edema. I. The Relation of Reduction of Serum Proteins to Edema and the Pathological Anatomy Accompanying Plasmapheresis.

2. Van Slyke, D. D., and Neill, J. M., J. Biol. Chem., 1924, 1xi, 523. The Determination of Gases in Blood and Other Solutions by Vacuum Extraction and Manometric Measurement.

3. Van Slyke, D. D., J. Biol. Chem., 1923, lviii, 523. The Determination of Chlorides in Blood and Tissues.

4. Benedict, S. R., and Theis, R. C., J. Biol. Chem., 1924, 1xi, 63. A Modification of the Molybdic Method for the Determination of Inorganic Phosphorous in Serum.

5. Stadie, W. C., and Ross, E. C., J. Biol. Chem., 1925, 1xv, 735. A Micro Method for the Determination of Base in Blood and Serum and Other Biological Materials.

6. Folin, O., and Wu, H., J. Biol. Chem., 1919, xxxviii, 81. A System of Blood Analysis.

7. Clark, E. P., and Collip, J. B., J. Biol. Chem., 1925, 1xiii, 461. A Study of the Tisdall Method for the Determination of Blood Serum Calcium with a Suggested Modification.

8. Howe, P. E., J. Biol. Chem., 1923, lvii, 241. The Relative Precipitating Capacity of Certain Salts when Applied to Blood Serum or Plasma and the Influence of the Cation in the Precipitation of Proteins.

9. Van Slyke, D. D., Hastings, A. B., Hiller, A., and Sendroy, J., Jr., J. Biol. Chem., 1928, lxxix, 769. Studies of Gas and Electrolyte Equilibria in 
Blood. XIV. The Amounts of Alkali Bound by Serum Albumin and Globulin.

10. Van Slyke, D. D., Wu, H., and McLean, F. C., J. Biol. Chem., 1923, lvi, 765. Studies of Gas and Electrolyte Equilibria in Blood. V. Factors Controlling the Electrolyte and Water Distribution in the Blood.

11. Peters, J. P., Wakeman, A. M., Eisenman, A. J., and Lee, C., J. Clin. Invest., 1929, vi, 577. Total Acid-Base Equilibrium of Plasma in Health and Disease. XII. A Study of Renal Edema.

12. Peters, J. P., Wakeman, A. M., and Eisenman, A. J., J. Clin. Invest., 1927, iii, 491. The Plasma Proteins in Relation to Blood Hydration. III. The Plasma Proteins in Malnutrition.

13. Blackfan, K. D., and Hamilton, B., Bull. Johns Hopkins Hosp., 1927, xli, 322. A Study of the Inorganic Constituents of the Serum in Children with Acute Nephritis.

14. Loeb, R. F., Atchley, D. W., and Palmer, W. W., J. Gen. Physiol., 1922, iv, 591. On the Equilibrium Condition Between Blood Serum and Serous Cavity Fluids.

15. Hastings, A. B., Salvesen, H. A., Sendroy, J., Jr., and Van Slyke, D. D., J. Gen. Physiol., 1927, viii, 701. Studies of Gas and Electrolyte Equilibria in the Blood. IX. The Distribution of Electrolytes Between Transudates and Serum.

16. Greene, C. H., Bollman, J. L., Keith, N. M., and Wakefield, E. G., J. Biol. Chem., 1931, xci, 203. The Distribution of Electrolytes Between Serum and Transudates.

Greene, C. H., and Power, M. H., J. Biol. Chem., 1931, xci, 183. The Distribution of Electrolytes Between Serum and the in Vivo Dialysate.

17. Van Slyke, D. D. Factors Affecting the Distribution of Electrolytes, Water and Gases in the Animal Body. J. B. Lippincott Co., Philadelphia, 1926.

18. Hamilton, B., J. Biol. Chem., 1925, 1xv, 101. A Comparison of the Concentrations of Inorganic Substances in Serum and Spinal Fluid.

19. Muntwyler, E., Way, C. T., and Pomerene, E., J. Biol. Chem., 1931, xcii, 733. A Comparison of the Chloride and Bicarbonate Concentrations Between Plasma and Spinal Fluid and Plasma and Ascitic Fluid in Reference to the Donnan Equilibrium.

20. Salvesen, H. A., and Linder, G. C., J. Biol. Chem., 1923, lviii, 617. Observations on the Inorganic Bases and Phosphates in Relation to the Protein of Blood and Other Body Fluids in Bright's Disease and in Heart Failure.

21. Marrack, J., and Thacker, G., Biochem. J., 1926, xx, 580. The State of Calcium in Body Fluids.

22. Peters, J. P., and Eiserson, L., J. Biol. Chem., 1929, lxxxiv, 155. The Influence of Protein and Inorganic Phosphorus on Serum Calcium.

23. Stearns, G., and Knowlton, G. C., J. Biol. Chem., 1931, xcii, 639. The Lack of Relationship Between the Calcium, Protein and Inorganic Phosphorus of the Serum of Non-Nephritic Children. 